\title{
Drivers of structural convergence: Accounting for model uncertainty and reverse causality
}

\author{
Krzysztof Beck
}

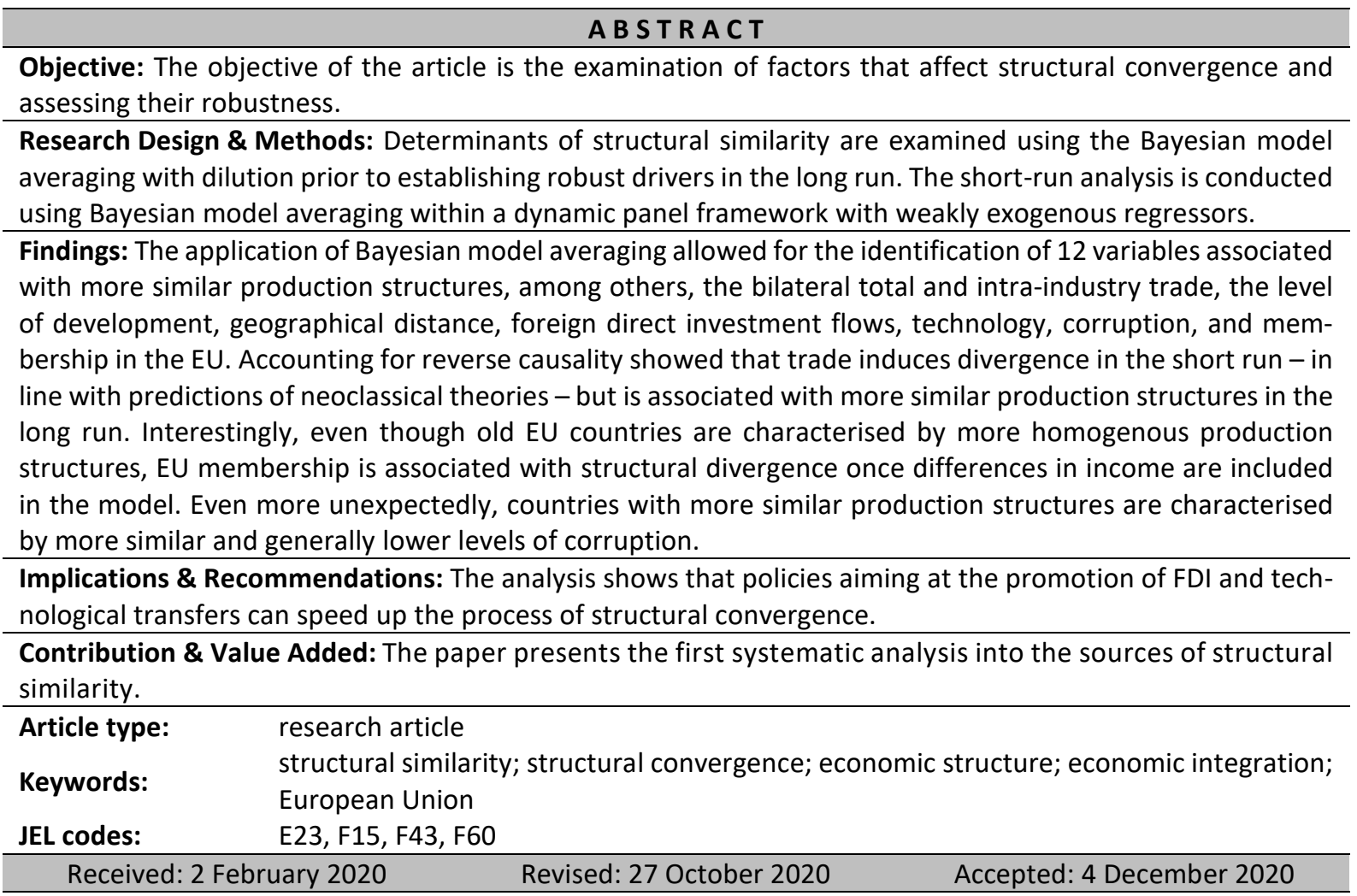

Suggested citation:

Beck, K. (2021). Drivers of structural convergence: Accounting for model uncertainty and reverse causality. Entrepreneurial Business and Economics Review, 9(1), 189-208. https://doi.org/10.15678/EBER.2021.090112

\section{INTRODUCTION}

Structural similarity is one of the main issues of European integration. Countries with similar production structures are prone to more symmetrical shocks and, consequently, a higher degree of business cycle synchronisation (Beck, 2013, 2014, 2019). In turn, business cycle synchronisation is a precondition for the formation of an effectively functioning monetary union. This topic has recently become more important as more and more authors are reporting business cycle divergence in the European Union (Beck \& Janus, 2013; Degiannakis et al., 2014; Bekiros et al., 2015; Ferroni \& Klaus, 2015; Campos \& Macchiarelli, 2016; Grigoraş \& Stanciu, 2016; Coppola, lanuario, Chinnici, Di Vita, Pappalardo, \& D'Amico, 2018; Janus, 2019; Beck \& Stanek, 2019; Beck, 2020). In light of the above, it is somewhat puzzling that research into structural similarity is remarkably scarce. Authors deal with specialisation patterns (e.g. Chiappini, 2014) and to a lesser extent, its determinants (e.g. Vechiu \& Makhlouf, 2014). Moreover, there has been tremendous interest in the similarities of trade structure (e.g. Van 
Biesebroeck, 2011), i.e. intra-industry trade and its impacting factors (e.g. Zhang \& Clark, 2009; Kinnunen, Androniceanu, \& Georgescu, 2019).

The research into structural similarity sensu stricto is relatively narrow. Höhenberger and Schmiedeberg (2008) describe structural convergence for Western European countries on a threesector level and in less technology-intensive sectors with divergence in technology-intensive manufacturing. Olczyk and Lechman (2011) report the progressing structural convergence between Germany and Visegrad countries. Grodzicki (2014) investigates the structural similarities between 25 EU member states at a three-sector level and for subsectors of manufacturing and services. He notices that European economies are becoming more homogenous at the three-sector level but are clustering at the lower level of aggregation.

To the best of my knowledge, there were only two attempts so far to examine structural similarity's determinants. Wacziarg (2004) found that structural convergence is affected by the difference in the level of real GDP per capita and differences in factor endowments (capital per worker, human capital, and population) in a sample of 120 countries. Using data on Portuguese counties, Crespo and Fontoura (2009) report that a common border, geographical distance, differences in factor endowments (capital, human capital), differences in real GDP per capita, and the centrality of location are associated with structural convergence.

The aforementioned void in the literature prompted my inquiry into the determinants of structural similarity presented here that could fill the gap in the existing literature. The relevancy of structural convergence for the issues of currency union has motivated the choice of the sample of European Union member states, as the results might be directly applicable to policy consideration. At the same time, we should remember that structural convergence is not a policy goal on its own; it is one of the measures to assure a more symmetrical distribution of shocks and - through that - enable a more effective monetary and fiscal policy implementation (Androniceanu, Gherghina, \& Ciobanasu 2019). Differences in production structure might reflect patterns of comparative advantage and facilitate the effective allocation of resources.

As the research into the subject of structural convergence is scarce, this paper undertakes the goal of providing a pervasive look at the sources of structural convergence. In order to accomplish this, the paper assumes an empirical approach to the verification of the relevance of 54 potential determinants of structural similarity taken from previous research and from the literature on structural change and international trade. In order to assess which of these variables are, in fact, associated with more similar production structures, I utilised Bayesian model averaging (BMA). After all, BMA is perfectly tailored for dealing with model uncertainty, especially in cases when there is insufficient prior knowledge available. In this setting, the obtained result could serve as a benchmark for future research both in terms of theory and practice. This part of the analysis is static in nature and elucidates long-run relationships between structural convergence and its determinants, while ignoring the potential endogeneity and dynamic nature of the relationship between the examined variables. Accordingly, the short-run relationships are examined further using the Moral-Benito (2016) econometric framework based on the likelihood function for dynamic panel models with weakly exogenous regressors and fixed effects.

The rest of the article is organised as follows. Section 2 provides a literature review. Section 3 describes data and estimation strategy, while section 4 describes empirical results. The last section concludes.

\section{LITERATURE REVIEW}

The problem of structural convergence was analysed indirectly in the literature on international trade. On the one hand, the neoclassical model of trade predicts that countries with different relative factor abundance are characterised by less similar production structures (Fenstra, 2015). On the other hand, models with monopolistic competition and increasing returns, reconcile growing trade with structural similarity (Krugman, 1979, 1980). The former shows that bilateral trade is directly associated with structural divergence and differences in factor abundance - indirectly; while the latter links intra-industry trade with convergence. Wacziarg (2004) and Crespo and Fontoura (2009) report that differences in factor abundance influence structural similarity, while Wacziarg (2004) shows that the impact 
of trade is fragile. Baxter and Kouparritsas (2003) demonstrate that there is no apparent connection between trade structure and industrial structure of the economy.

The second strand of the literature that deals with structural convergence is the structural change research (Krüger, 2010; Herrendorf et al., 2014; Święcki, 2017; van Neuss, 2019). Caselli and Coleman (2001) and Buera et al. (2015) demonstrate in both theoretical models and practice that change in the skill structure between low-skilled and high-skilled workers drives structural change, consequently confirming the role of factor endowments in structural convergence. The role of income holds a very prominent role in structural change literature. Scholars link changes in income with the evolution of economic structure using Engel's Law (Foellmi \& Zweimüller, 2008; Boppart, 2014; Caron et al., 2014) or changes in sectoral productivities associated with workers skill levels (Bonatti \& Felice, 2008; Duarte \& Restuccia, 2010; Buera et al., 2015; Caron et al., 2017), which has evidences both at the level of enterprises (Bilan et al., 2020; Stachova et al., 2020) and for the national economy (Popoola, 2019). Imbs and Wacziarg (2003) record an empirical observation that with the increasing level of GDP per capita, countries go through a U-shaped pattern of specialisation. With increasing GDP per capita, economies first diversify in terms of structure and after reaching some critical point, start to re-specialise. This result is confirmed by Koren and Tenreyro (2007) for a highly diversified set of countries and by Partekra (2009) for the European Union. This outcome suggests that at high levels of per capita income, countries will get increasingly less similar in terms of production structure unless they are going to specialise within the same sectors as a result of cross-border vertical integration (Fixler \& Siegel, 1999; OECD, 2013).

The impact of international trade flows on structural change is advocated by Matsuyama (2009), Imbs et al. (2012) and Bielekova and Pokrivcak (2020) in their theoretical models and empirical investigations. Jones (2013) stresses the role of input-output linkages in the evolution of economic structure, while Peneder and Streicher (2018) extend this notion to the introduction of vertical integration in global value chains. Meanwhile, Ngai and Pissarides (2007) advocate the importance of differences in sectoral total factor productivity growth rates for structural change. Stijepic and Wagner (2015) and Felice (2016) demonstrate the role of government spending and public investment on sectoral composition, respectively.

\section{RESEARCH METHODOLOGY}

\section{Data and measurement}

My analysis covers 26 European Union countries (without Croatia and Malta). All variables are in bilateral form for 26 countries, which amounts to 325 country pairs. The research covers the 1995-2015 period. In the cross-sectional data setting, all examined variables represent the mean values for the entire examined period. The mean values are utilised to capture the long-run relationship between structural similarity and its potential determinants.

In the cross-sectional setting, the regressand measures the similarity of production structures of two countries, calculated as bilateral Krugman specialisation index (1991) for sectoral value added with the economy divided in 35 sectors:

$$
K S I_{i j}=\frac{1}{T} \sum_{t=1}^{T} \sum_{l=1}^{L}\left|v_{l i t}-v_{l j t}\right|
$$

in which $v_{\text {lit }}$ denotes the share of sector / in value added for country $i$ at time $t$, while $L=35$ is an overall number of different industries in the economy. The KSI value ranges from 0 to 2 , in which production shares in the two countries are identical with the value of the measure equal to 0 . Data for $K S I_{i j}$ was extracted from the World Output-Input Database (WOID) and is annual.

A list of regressors with sources of data used to calculate them and descriptions of their constriction is provided in Table 1 . In total, the set is made of 54 regressors described in the first section, complemented with gravity variables and macroeconomic, institutional, and cultural indicators.

The analysis of cross-sectional data allowed for the identification of twelve variables that influence structural similarity over the long run: MB, RGDPpc, BCIPROD, RGDPpCPROD, IIT, BCIDIFF, PATENT, 
LNDGEO, CAPARABLE, LNTRADE, FDID, and OLDEU. Consequently, in the second stage of the analysis, those variables were examined further in the panel data setting; except for MB, LNDGEO, and OLDEU, which are time-invariant. The second stage involves dynamic panel Bayesian model averaging with weakly exogenous regressors, which dictated the elimination of MB, LNDGEO, and OLDEU, as they are time-invariant and are accounted for by fixed effects. The data in the panel setting is at annual frequency and covers the same sample of countries and time period as covered under the cross-sectional data setting, yet this time all the variables are calculated for a given year instead of being averaged over the entire period. Consequently, the sample comprises 325 country pairs, 20 years, and a total of 6500 observations.

Table 1. Data description

\begin{tabular}{|c|c|c|}
\hline VARIABLE & DESCRIPTION & SOURCE \\
\hline AGROWTH & $\begin{array}{l}\text { AV of the difference between mean GDP growth rates over the 1999-2011 } \\
\text { period }\end{array}$ & PWT \\
\hline ARABLE & AAV of the difference in arable land & WB \\
\hline ARABLEpw & AAV of the difference in arable land per worker & PWT \& WB \\
\hline $\mathrm{B}$ & common border dummy & - \\
\hline BCIDIFF & MV of the AV of the difference in Bayesian Corruption Index & Standaert (2015) \\
\hline BCIPROD & MV of the product of the values of Bayesian Corruption Index & Standaert (2015) \\
\hline CAP & AAV of the difference in capital & PWT \\
\hline CAPAREABLE & AAV of the difference in capital to arable land ratio & PWT \& WB \\
\hline CAPLAND & AAV of the difference in capital to land ratio & PWT \& WB \\
\hline CPW & AAV of the difference in capital per worker & PWT \\
\hline CPWARABLE & AAV of the difference in capital per worker to arable land ratio & PWT \& WB \\
\hline CPWLAND & AAV of the difference in capital per worker to land ratio & PWT \& WB \\
\hline EMPL & AAV of the difference in employment & PWT \\
\hline EMPLARABLE & AAV of the difference in employment to arable land ratio & PWT \& WB \\
\hline EMPLLAND & AAV of the difference in employment to land ratio & PWT \& WB \\
\hline EPCpc & AAV of the difference in electricity consumption per capita & WB \\
\hline EU & $\begin{array}{l}\text { average number of years both countries spend in the EU together between } \\
1999 \text { and } 2011\end{array}$ & - \\
\hline EXCHANGE & coefficient of variation of bilateral nominal exchange rate & AMECO \\
\hline FDID & AAV of the difference in FDI flows & UNCTAD \\
\hline GOV & AAV of the difference of government shares in GDP & PWT \\
\hline HUMAN & AAV of the difference in human capital & PWT \\
\hline HUMANARABLE & AAV of the difference in human capital to arable land ratio & PWT \& WB \\
\hline HUMANCAP & AAV of the difference in human capital to capital ratio & PWT \\
\hline HUMANEMPL & AAV of the difference in human capital to employment ratio & PWT \\
\hline HUMANLAND & AAV of the difference in human capital to land ratio & PWT \& WB \\
\hline IIT & $\begin{array}{l}\text { MV of the ratio of bilateral intra-industry trade to total trade in intermediate } \\
\text { goods }\end{array}$ & WOID \\
\hline IITT & $\begin{array}{l}\text { MV of the product of (bilateral intra-industry trade to total trade in interme- } \\
\text { diate goods and the ratio of imports and export to the sum of two countries } \\
\text { GDPs }\end{array}$ & WOID \& DOT \\
\hline INFVAR & $\begin{array}{l}\text { AV of the difference between standard deviations of inflation rate over the } \\
1999-2011 \text { period }\end{array}$ & WEO \\
\hline IUp100 & AAV of the difference in number of internet users per 100 inhabitants & WB \\
\hline $\mathrm{L}$ & common language dummy (at least on official common language) & - \\
\hline LAND & AAV of the difference in land & WB \\
\hline LANDpc & AAV of the difference in land per capita & WB \\
\hline LNDGEO & natural logarithm of geographical distance between capitals & Google Maps \\
\hline LNPOPPROD & MV of the natural logarithm of population product & PWT \\
\hline LNRGDPPROD & MV of the natural logarithm of real GDP product & PWT \\
\hline LNTRADE & natural logarithm of the average value of real imports plus exports & DOT \& PWT \\
\hline MA & dummy variable for a pair of countries sharing a marine border & - \\
\hline
\end{tabular}




\begin{tabular}{|c|l|c|}
\hline VARIABLE & \multicolumn{1}{|c|}{ DESCRIPTION } & SOURCE \\
\hline MB & dummy variable for a pair of countries with access to the ocean or the sea & - \\
\hline MU & $\begin{array}{l}\text { average number of years both countries spend in the Eurozone together be- } \\
\text { tween 1999 and 2011 }\end{array}$ & WB \\
\hline OILPC & AAV of the difference in the number of internet users per 100 inhabitants & - \\
\hline OLDEU & $\begin{array}{l}\text { dummy variable for a pair of countries that were members of the EU before } \\
2004\end{array}$ & PWT \\
\hline OPEN & $\begin{array}{l}\text { AAV of the difference in imports+exports shares of GDP between two coun- } \\
\text { tries }\end{array}$ & WB \\
\hline PATENT & AAV of the difference in number of patents per 1 mln inhabitants & PWT \\
\hline POPDIFF & AAV of the difference in population & PWT \\
\hline RGDPDIFF & AAV of the difference in real GDP & PWT \\
\hline RGDPpC & AAV of the natural logarithm of the difference in real GDP per capita & PWT \\
\hline RGDPpCPROD & MV of the real GDP per capita product & PWT \\
\hline TFP & $\begin{array}{l}\text { correlation coefficient of growth rates of total factor productivity in two } \\
\text { countries }\end{array}$ & DOT \& WB \\
\hline TRADE1 & MV of the ratio of imports and export to the sum of two countries GDPs & DOT \\
\hline TRADE2 & MV of the ratio of imports and export to the sum of two countries total trades & IMF \\
\hline TRANS & dummy variable for a pair of transition countries & IMF WEO \\
\hline UNEMP & AAV of the difference between unemployment rates in two countries & WB \\
\hline URBAN & AV of the difference in the urban population & PWT \& WB \\
\hline URBANshare & AAV of the difference in share of the urban population & P \\
\hline
\end{tabular}

Abbreviations: MV - average value; AV - absolute value; AAV - average absolute value; PWT - Penn World Tables (Feenstra et al., 2015); WB - World Bank; DOT - IMF Directions of Trade; UNCTAD - United Nations Conference on Trade and Development; WEO - IMF World Economic Outlook.

Source: own elaboration.

\section{Estimation strategy}

\section{Cross-sectional setting}

In order to find robust drives of structural convergence, this research applied Bayesian model averaging (BMA) and utilised vast prior structure to deal with multicollinearity. Accurate and detailed review of BMA can be found in Hoeting et al. (1999) and Beck (2017). Moreover, a detailed discussion on the choice of prior structure within the BMA framework was prepared by Fernández et al. (2001), Ley and Steel (2009, 2012), Feldkircher and Zeugner (2009), and Eicher et al. (2011). The list of regressors used in the research suffered considerably from multicollinearity. Therefore, the methods applied in this paper were truncated to deal with this issue. Consequently, I employed two different estimation strategies employing prior structure designed to deal with multicollinearity.

The first strategy (Strategy I) utilised a uniform model prior (Sala-I-Martin et al., 2004; Ley \& Steel, 2009) complemented with a function accounting for multicollinearity (George, 2010) to calculate prior model probabilities:

$$
P\left(M_{j}\right) \propto\left|R_{j}\right|^{0.5}\left(\frac{1}{2}\right)^{K}
$$

in which $K=(54)$ denoted total number of regressors used in the analysis. The figure $\left|R_{j}\right|$ denoted the determinant of correlation matrix for all the covariates included in model $j$. Within the uniform model, prior model probabilities on all considered models equalled $\left(=\frac{1}{2^{K}}=1 / 2^{54}\right)$. Consequently, the determinant of the correlation matrix $\left|R_{j}\right|$ in (2) played the key role in determining the distribution of prior probability. The high degree of multicollinearity in the considered model $j$ was associated with the value of the determinant of the correlation matrix $\left|R_{j}\right|$ close to 0 and, accordingly, the lower prior probability assigned to model j. Posterior probabilities were calculated with the use of $\mathrm{MC}^{3}$ sampler (the Markov Chain Monte Carlo Model Composition; Madigan et al., 1995). The correlation coefficient between the analytical and $\mathrm{MC}^{3}$ posterior model probabilities for the best 10000 models was used as a measure to assess the convergence of the chain. 
In the second strategy (Strategy II), a binomial-beta model prior (Ley \& Steel, 2009) was utilised:

$$
P\left(M_{j}\right) \propto \Gamma\left(1+k_{j}\right) \cdot \Gamma\left(\frac{K-E M S}{E M S}+K-k_{j}\right)
$$

in which the $E M S=\frac{K}{2}$ probability of each model size equalled $\left(=\frac{1}{K+1}\right)$. Multicollinearity was dealt with by using tessellation prior with the Metropolis-Hestings algorithm. In other words, dilution was implemented through the MCMC search, while tessellation was achieved by the 'Spinner Process' (George, 2010). For tessellation prior, the correlation coefficient of analytical and $\mathrm{MC}^{3}$ was inadequate to assess the convergence of the chain. Consequently, empirical exercise was repeated ten times, with different numbers of burn-ins and iterations. In all cases, the obtained results were virtually the same as the ones reported here. ${ }^{1}$

The tone of BMA advantages offered the possibility to apply g prior (Zellner, 1986). The rule known as a 'benchmark prior' - proposed by Fernández et al. (2001) - indicated that risk inflation criterion (RIC) designed by Foster and George (1994) was the optimal choice for a dataset with 325 observations and 54 covariates. Nevertheless, I submitted the results to vast robustness checks by changes in both model prior and g prior.

The assessment of the models based on posterior model probabilities (PMP) calculated by combining model specific value of the likelihood function through the Bayes theorem (Beck, 2020b):

$$
P M P=p\left(M_{j} \mid y\right)=\frac{l\left(y \mid M_{j}\right) \cdot p\left(M_{j}\right)}{p(y)}=\frac{l\left(y \mid M_{j}\right) \cdot P\left(M_{j}\right)}{\sum_{j=1}^{2^{K}} l\left(y \mid M_{j}\right) \cdot P\left(M_{j}\right)}
$$

in which $l\left(y \mid M_{j}\right)$ denoted model-specific marginal likelihood while $y$ - a given data set. Within this setting, posterior model probabilities could have been treated as weights because $p(y)=$ $\sum_{j=1}^{2^{K}} l\left(y \mid M_{j}\right) * P\left(M_{j}\right)$. Consequently, the posterior mean (PM) for the coefficient $\beta_{i}$, independent of the space of the models was defined as (Beck, 2020c):

$$
P M=E\left(\beta_{i} \mid y\right)=\sum_{j=1}^{2^{K}} P\left(M_{j} \mid y\right) \cdot \hat{\beta}_{i j}
$$

in which $\beta_{i j}=E\left(\beta_{i} \mid y, M_{j}\right)$ was $\beta_{i}$ estimated with ordinary least squares for the model $M_{j}$. The posterior standard deviation (PSD) was given by:

$$
P S D=\sqrt{\sum_{j=1}^{2^{K}} P\left(M_{j} \mid y\right) \cdot V\left(\beta_{j} \mid y, M_{j}\right)+\sum_{j=1}^{2^{K}} P\left(M_{j} \mid y\right) \cdot\left[\hat{\beta}_{i j}-E\left(\beta_{i} \mid y, M_{j}\right)\right]^{2}}
$$

in which $V\left(\beta_{j} \mid y, M_{j}\right)$ was the conditional variance of $\beta_{j}$ in the model $M_{j}$. To enable the relative strength comparison of analysed drivers of structural convergence, I report standardised posterior mean (SPM) and standardised posterior standard deviation (Doppelhofer \& Weeks, 2009), alongside PM and PSD.

The posterior inclusion probability (PIP) - i.e. the probability of including the regressor in the model after seeing the data - was given by:

$$
P I P=P\left(x_{i} \mid y\right)=\sum_{j=1}^{2^{K}} 1\left(\varphi_{i}=1 \mid y, M_{j}\right) \cdot P\left(M_{j} \mid y\right)
$$

in which $\varphi_{i}=1$ signified the inclusion of variable $x_{i}$ in a given model. A variable was classified as robust if the PIP was above 0.5 , which was the equivalent of no prior information. More details on the interpretation of the results will be given in subsections 3.1 and 3.2.

The posterior probability of a positive sign of $\beta_{j}-P(+)$ was given by:

\footnotetext{
${ }^{1}$ The results are available upon request.
} 


$$
P(+)=P\left[\operatorname{sign}\left(x_{i}\right) \mid y\right]=\left\{\begin{array}{cc}
\sum_{j=1}^{2^{K}} P\left(M_{j} \mid y\right) \cdot C D F\left(t_{i j} \mid M_{j}\right), & \text { if } \operatorname{sign}\left[E\left(\beta_{i} \mid y\right)\right]=1 \\
1-\sum_{j=1}^{2^{K}} P\left(M_{j} \mid y\right) \cdot C D F\left(t_{i j} \mid M_{j}\right), & \text { if } \operatorname{sign}\left[E\left(\beta_{i} \mid y\right)\right]=-1
\end{array}\right.
$$

In which $C D F$ denotes cumulative distribution function and $t_{i j} \equiv\left(\hat{\beta}_{i} / \widehat{S D}_{i} \mid M_{j}\right)$.

The Bayesian model averaging framework enabled the assessment of the nature of relationships between regressors by using jointness measures. Ley and Steel (2007) measure was given by:

$$
L S_{(i h)}=\ln \left[\frac{P(i \cap h \mid y)}{P(i \cap \bar{h} \mid y)+P(\bar{\imath} \cap h \mid y)}\right]=\ln \left[\frac{P(i \cap h \mid y)}{P(i \mid y)+P(h \mid y)-2 P(i \cap h \mid y)}\right]
$$

in which $i$ and $h$ represent two different covariates. For $L S>$, the two regressors were classified as strong complements, for $2>L S>1$ covariates were complements, for $1>L S>-1$ the variables were unrelated, for $-1>L S>-2$ the regressors were significant substitutes, and $-2>L S$ characterised strong substitutes. All the estimations with cross-sectional data were performed with the BMS package (Feldkircher \& Zeugner, 2009) for R.

\section{Panel data setting}

In the panel data setting, Moral-Benito (2016) framework was used to account for endogeneity between structural similarity and its potential drivers. The method utilised dynamic panel setting and allowed for dealing with both model uncertainty and reverse causality. In order to account for both those issues, the Moral-Benito framework utilises the likelihood function for dynamic panel models with weakly exogenous regressors and fixed effects. Accordingly, for the panel data setting, the main equation was given by:

$$
y_{i t}=\alpha y_{i t-1}+x_{i t} \beta+\eta_{i}+\zeta_{t}+v_{i t} \quad(i=1, \ldots, N ; t=1, \ldots, T)
$$

in which $y_{i t}$ was a structural convergence measure for country pair $i$ at time $t, x_{i t}$ was a vector of examined KSI drivers, $\beta$ was a parameter vector, $\eta_{i}$ is a country-pair-specific fixed effect, $\zeta_{t}$ was a period-specific shock, and $v_{i t}$ was a shock to structural similarity. Formally, the assumption of weak exogeneity was expressed as:

$$
\mathrm{E}\left(v_{i t} \mid y_{t}^{t-1}, x_{i}^{t}, \eta_{i}\right)=0 \quad(i=1, \ldots, N ; t=1, \ldots, T)
$$

in which $y_{t}^{t-1}=\left(y_{i 0}, \ldots, y_{i t-1}\right)^{\prime}$ and $x_{t}^{t}=\left(x_{i 0}, \ldots, x_{i t}\right)^{\prime}$. Consequently, weak exogeneity implied that the lagged depended variable, fixed effects, and the current values of the covariates were uncorrelated with current shocks. At the same time, I allowed all of them to correlate with each other.

Moral-Benito (2013) derived the likelihood function in the described setting. I accomplished that by augmenting equation (10) with reduced-form equations that captured the unrestricted feedback process given by:

$$
x_{i t}=\gamma_{t 0} y_{i 0}+\cdots+\gamma_{t, t-1} y_{i, t-1}+\Lambda_{t 1} x_{i 0}+\cdots+\Lambda_{t, t-1} x_{i t-1}+c_{t} \eta_{i}+\vartheta_{i t}
$$

in which $t=2, \ldots, T$ and $c_{t}$ was the $k \times 1$ vector of parameters. For $h<t, \gamma_{t h}$ was a $k \times 1$ vector $\left(y_{t h}^{1}, \ldots, y_{t h}^{k}\right)^{\prime} h=0, \ldots, T-1 ; \Lambda_{t h}$ was a $k \times k$ matrix of parameters, and $\vartheta_{i t}$ was a $k \times 1$ vector of prediction errors. Finally, the mean vector and the covariance matrix of the joint distribution of the initial observations and the individual effects $\eta_{i}$ were unrestricted:

$$
\begin{gathered}
y_{i 0}=c_{0} \eta_{i}+v_{i t} \\
x_{i 1}=\gamma_{10} y_{i 0}+c_{1} \eta_{i}+\vartheta_{i t}
\end{gathered}
$$

in which $c_{0}$ was a scalar, while $c_{1}$ and $\gamma_{10}$ were $k \times 1$ vectors. The model described in the equations (10) and (12-14) was characterised by the natural logarithm of the likelihood function given by: 


$$
\log f(\text { data } \mid \theta) \propto \frac{N}{2} \log \operatorname{det}\left(B^{-1} D \Sigma D^{\prime B^{\prime-1}}\right)-\frac{1}{2} \sum_{i=1}^{N}\left\{R_{i}^{\prime}\left(B^{-1} D \Sigma D^{\prime B^{\prime-1}}\right)^{-1} R_{i}\right\}
$$

in which $R_{i}=\left(y_{i 0}, x^{\prime}{ }_{i 1}, y_{i 1}, \ldots, x^{\prime}{ }_{i T}, y_{i T}\right)^{\prime}$ was a vector of observable variables, while $\Sigma=$ $\operatorname{diag}\left\{\sigma_{\eta}^{2}, \sigma_{v_{0}}^{2}, \Sigma_{\vartheta_{1}}, \sigma_{v_{1}}^{2}, \ldots, \Sigma_{\vartheta_{T}}, \sigma_{v_{T}}^{2}\right\}$ was the block-diagonal variance-covariance matrix of $U_{i}=$ $\left(\eta_{i}, v_{i 0}, \vartheta^{\prime}{ }_{i 0}, v_{i 1}, \ldots, \vartheta^{\prime}{ }_{i T}, v_{i T}\right) . B$ was a matrix of coefficients given by:

$$
B=\left[\begin{array}{ccccccccc}
1 & 0 & 0 & 0 & 0 & \cdots & 0 & 0 & 0 \\
-\gamma_{10} & I_{0} & 0 & 0 & 0 & \cdots & 0 & 0 & 0 \\
-\alpha & -\beta^{\prime} & 1 & 0 & 0 & \cdots & 0 & 0 & 0 \\
-\gamma_{20} & -\Lambda_{21} & -\gamma_{21} & I_{k} & 0 & \cdots & 0 & 0 & 0 \\
0 & 0 & -\alpha & -\beta^{\prime} & 1 & \cdots & \vdots & \vdots & \vdots \\
\vdots & \vdots & \vdots & \vdots & \vdots & \ddots & 0 & 0 & 0 \\
-\gamma_{T 0} & -\Lambda_{T 1} & -\gamma_{T 1} & -\Lambda_{T 2} & -\gamma_{T 2} & \cdots & -\gamma_{T, t-1} & I_{k} & 0 \\
0 & 0 & 0 & 0 & 0 & \cdots & -\alpha & -\beta^{\prime} & 1
\end{array}\right]
$$

and $\mathrm{D}$ was a matrix of coefficients given by:

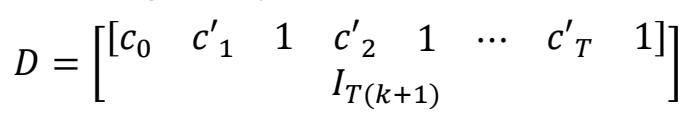

The Moral-Benito approach $(2013,2016)$ allows for dealing with endogeneity and model uncertainty in a dynamic panel setting. On the other hand, the complex nature of the likelihood function given in equation (15)'s numerical optimisation was very time-consuming, and consequently, estimation with all 43 regressors became infeasible. As a result, the method was able to deal with a far lower number of potential regressors compared to with a conventional BMA approach. Therefore, the abovementioned Moral-Benito method was applied to a subset of variables classified as robust determinants of structural similarity in cross-sectional analysis. To make the calculation of the maximum likelihood easier, all the regressors utilised at this stage of the analysis were standardised.

Even though the likelihood function used in the Moral-Benito approach is vastly more complicated than simple likelihood used in the case of an OLS model, all Bayesian model averaging statistics were calculated in the same way.

Therefore, the robustness of structural similarity drivers could have been assessed with PIP, PM, and PSD. As recommended by Eicher et al. (2011) and Moral-Benito (2012) unit information prior (Kass \& Wasserman, 1995) was chosen for g prior, and Binomial-beta distribution was chosen for prior model probability. All the estimations in the panel data setting were obtained using the GAUSS code originally prepared by Moral-Benito (2016) and rewritten by the author of that paper.

\section{RESULTS AND DISCUSSION}

\section{Cross-sectional setting}

Table 2 reports the result of the BMA application. In this context, Kass and Raftery (1995) propose a detailed classification scheme with robustness as weak, positive, strong, or decisive when posterior inclusion probability is between 0.5 and $0.75,0.75$ and $0.95,0.95$ and 0.99 , or 0.99 and 1 , respectively. Accordingly, MB, RGDPpc, and BCIPROD were decisively robust, while RGDPpCPROD is strongly robust. IIT, PATENT, and BCIPROD were strongly or positively robust, depending on the employed strategy. LNTRADE was weakly robust in both strategies. Finally, LNDGEO, CAPARABLE, FDID, and OLDEU were weakly robust only in one strategy.

Marine border dummy (MB) was classified as robust with posterior inclusion probability amounting to one in both BMA specifications. The natural logarithm of the geographical distance (LNDGEO) was robust with PIP equal to 0.7 in Strategy I, while being fragile with 0.48 PIP in Strategy II; yet its posterior inclusion probability was very close to the critical value of 0.5 . Still, this variable could have been considered only weakly robust. The posterior mean for both variables was positive, which 
Table 1. BMA statistics in Strategy I and II

\begin{tabular}{|c|c|c|c|c|c|c|c|c|c|c|c|c|}
\hline \multirow{2}{*}{$\frac{\text { Strategy }}{\text { VARIABLE }}$} & & \multicolumn{6}{|c|}{ II } \\
\hline & PIP & PM & PSD & SPM & SPSD & $\mathrm{P}(+)$ & PIP & PM & PSD & SPM & SPSD & $\mathrm{P}(+)$ \\
\hline MB & 1.000 & 0.066 & 0.012 & 0.227 & 0.041 & 1.000 & 1.000 & 0.071 & 0.013 & 0.244 & 0.044 & 1.000 \\
\hline RGDPpc & 1.000 & & & 0.524 & & 1.000 & 1.000 & & & & & \\
\hline BCIPROD & 1.000 & 0.000 & 0.000 & 0.583 & 0.115 & 1.000 & 1.000 & 0.000 & 0.000 & 0.573 & \begin{tabular}{|l|}
0.109 \\
\end{tabular} & 1.000 \\
\hline RGDPpcPROD & 0.960 & 0.000 & 0.000 & 0.481 & 0.173 & 1.000 & 0.978 & 0.000 & 0.000 & 0.461 & \begin{tabular}{|l|}
0.152 \\
\end{tabular} & 1.000 \\
\hline IIT & 0.850 & -0.167 & 0.087 & -0.117 & 0.061 & 0.000 & 0.619 & -0.120 & 0.104 & -0.084 & 0.073 & 0.000 \\
\hline BCIDIFF & 0.762 & 0.002 & 0.001 & 0.167 & 0.111 & 1.000 & 0.682 & 0.002 & 0.001 & 0.142 & 0.112 & 1.000 \\
\hline & 0.734 & & & & & & & & & & & \\
\hline LNDGEO & 0.699 & 0.022 & 0.016 & 0.118 & 0.089 & 1.000 & 0.447 & 0.014 & 0.017 & 0.078 & 0.094 & 1.000 \\
\hline CAPARABLE & 0.593 & -0.000 & 0.000 & -0.192 & 0.185 & 0.001 & 0.364 & -0.000 & 0.000 & -0.115 & 0.171 & 0.002 \\
\hline LNTRADE & 0.535 & -0.009 & 0.010 & -0.165 & 0.174 & 0.000 & 0.693 & -0.014 & 0.010 & -0.246 & 0.183 & 0.000 \\
\hline FDID & 0.508 & 0.003 & 0.003 & 0.148 & 0.161 & 1.000 & 0.435 & 0.002 & 0.003 & 0.126 & 0.158 & 1.000 \\
\hline RGDPI & 0.456 & & & 0.212 & & \begin{tabular}{|l|}
1.000 \\
\end{tabular} & \begin{tabular}{|l|}
0.263 \\
\end{tabular} & & 0.000 & & & \\
\hline CAPLA & 0.409 & -0.001 & 0.002 & -0.126 & 0.199 & \begin{tabular}{|l|}
0.000 \\
\end{tabular} & \begin{tabular}{|l|}
0.275 \\
\end{tabular} & -0.001 & 0.002 & -0.111 & \begin{tabular}{|l|}
0.203 \\
\end{tabular} & 0.000 \\
\hline & 0.398 & 0.000 & 0.000 & 0.056 & 0.077 & 0.999 & 0.345 & 0.000 & 0.000 & 0.052 & 0.077 & 1.000 \\
\hline POPDIFF & 0.338 & -0.000 & 0.000 & -0.321 & 0.534 & \begin{tabular}{|l|}
0.032 \\
\end{tabular} & \begin{tabular}{|l|}
0.361 \\
\end{tabular} & -0.000 & 0.000 & -0.333 & 0.518 & 0.016 \\
\hline OLDEU & 0.303 & 0.024 & 0.042 & 0.093 & 0.164 & 0.999 & 0.562 & 0.055 & 0.057 & 0.215 & 0.222 & 1.000 \\
\hline & 0.262 & 0.000 & 0.000 & 0.310 & 0.598 & 0.997 & 0.278 & 0.000 & 0.000 & 0.311 & 0.563 & 0.992 \\
\hline EMPI & 0.241 & & 0.000 & 0.081 & 0.162 & 0.919 & 0.228 & & 0.000 & 0.081 & 0.160 & 0.971 \\
\hline $\mathrm{HU}$ & 0.239 & & 0.026 & 0.019 & 0.037 & 1.000 & \begin{tabular}{|l|}
0.172 \\
\end{tabular} & 0.010 & 0.024 & 0.015 & 0.035 & 1.000 \\
\hline & 0.235 & & 0.000 & -0.029 & 0.057 & 0.000 & 0.316 & -0.000 & 0.000 & -0.040 & 0.065 & 0.000 \\
\hline IUp100 & 0.162 & 0.000 & 0.001 & 0.022 & 0.056 & 1.000 & 0.100 & 0.000 & 0.000 & 0.013 & \begin{tabular}{|l|}
0.043 \\
\end{tabular} & 0.998 \\
\hline IITT & 0.155 & -0.764 & 1.945 & -0.018 & 0.045 & 0.000 & 0.088 & -0.435 & 1.546 & -0.010 & & 0.000 \\
\hline & 0.151 & & & & & & & & & & & \\
\hline & 0.116 & -0.0 & 0.062 & -0.038 & 0.113 & \begin{tabular}{|l|}
0.007 \\
\end{tabular} & & -0.066 & 0.095 & -0.119 & & 0.005 \\
\hline TRADE1 & 0.112 & -0.16 & 0.502 & -0.012 & 0.038 & 0.001 & 0.067 & -0.094 & 0.402 & -0.007 & 0.030 & 0.013 \\
\hline & 0.110 & -0.005 & 0.015 & -0.008 & 0.026 & 0.000 & 0.035 & -0.001 & 0.008 & -0.002 & 0.013 & 0.001 \\
\hline OILpc & 0.100 & 0.000 & 0.000 & 0.012 & 0.039 & 0.999 & 0.062 & 0.000 & 0.000 & 0.007 & 0.030 & 0.997 \\
\hline $\mathrm{TR}$ & 0.092 & & 0.178 & -0.010 & 0.036 & & \begin{tabular}{|l|}
0.065 \\
\end{tabular} & & 0.149 & -0.007 & & 0.007 \\
\hline & 0.08 & & 0.001 & 0.007 & & & & & 0.001 & & & 0.960 \\
\hline CPWA & 0.086 & 0.000 & 0.000 & 0.006 & 0.024 & \begin{tabular}{|l|}
0.998 \\
\end{tabular} & \begin{tabular}{|l|}
0.058 \\
\end{tabular} & 0.000 & 0.000 & 0.005 & 0.023 & 0.998 \\
\hline EXCHANGE & 0.073 & & 0.029 & 0.005 & 0.022 & 0.990 & 0.033 & & 0.020 & 0.002 & & 0.976 \\
\hline LNRGDPPROD & 0.070 & -0.001 & 0.004 & -0.012 & 0.069 & 0.066 & 0.054 & -0.002 & 0.014 & -0.039 & 0.233 & 0.172 \\
\hline LNPOPPROD & 0.055 & & & & 0.074 & & 0.091 & & & & & 0.952 \\
\hline & & & & & & & & & & & & 0.706 \\
\hline LANDpc & 0.050 & & 0.000 & 0.004 & 0.019 & 0.977 & 0.021 & 0.000 & 0.000 & 0.001 & 0.011 & 0.973 \\
\hline & 0.049 & & 0.070 & 0.005 & 0.024 & 0.993 & 0.038 & & 0.059 & 0.003 & & 0.987 \\
\hline HUMANCAP & 0.041 & -20.27 & 121.4 & -0.003 & 0.018 & 0.027 & 0.023 & -10.924 & 88.347 & -0.002 & 0.013 & 0.020 \\
\hline EMPLARAI & 0.038 & & & & & 0.752 & & & 0.000 & & & 0.530 \\
\hline & & & & & & & & & & & & 0.010 \\
\hline TRANS & 0.033 & -0.001 & 0.006 & -0.003 & 0.018 & 0.016 & \begin{tabular}{|l|}
0.058 \\
\end{tabular} & -0.002 & 0.010 & -0.006 & \begin{tabular}{|l|}
0.028 \\
\end{tabular} & 0.006 \\
\hline & 0.031 & 0.000 & 0.003 & 0.001 & 0.010 & 0.767 & 0.014 & 0.000 & 0.002 & 0.000 & 0.006 & 0.818 \\
\hline ARABLE & 0.028 & & 0.000 & 0.001 & 0.008 & 0.983 & 0.024 & & 0.000 & 0.001 & 0.009 & 0.998 \\
\hline ARABLEpw & 0.026 & & 0.000 & 0.003 & 0.022 & 0.970 & 0.019 & & 0.000 & 0.003 & 0.025 & 0.958 \\
\hline & & & & & & & & & & & & 0.111 \\
\hline HUMANARABLE & 0.022 & & & & & 0.894 & 0.010 & & 0.006 & 0.000 & 0.006 & 0.857 \\
\hline $\mathrm{B}$ & 0.021 & -0.000 & 0.003 & -0.001 & 0.008 & \begin{tabular}{|l|}
0.062 \\
\end{tabular} & 0.016 & -0.000 & 0.003 & -0.001 & 0.007 & 0.044 \\
\hline AGROWTH & 0.020 & 0.004 & 0.064 & 0.000 & 0.005 & 0.902 & 0.009 & 0.002 & 0.042 & 0.000 & 0.003 & 0.896 \\
\hline UNEMP & 0.019 & 0.000 & 0.000 & 0.000 & 0.005 & 0.516 & 0.011 & 0.000 & 0.000 & 0.000 & 0.004 & 0.600 \\
\hline CAP & 0.018 & & & -0.000 & & 0.685 & 0.024 & & 0.000 & -0.002 & & 0.426 \\
\hline $\mathrm{L}$ & 0.017 & -0.000 & 0.003 & -0.000 & 0.005 & 0.267 & 0.009 & & 0.002 & -0.000 & 0.003 & 0.268 \\
\hline MU & 0.014 & 0.000 & 0.002 & 0.000 & 0.007 & 0.674 & 0.011 & 0.000 & 0.002 & 0.000 & 0.005 & 0.498 \\
\hline HUMANEMPL & 0.012 & -4.986 & 263.469 & -0.000 & 0.006 & \begin{tabular}{|l|}
0.406 \\
\end{tabular} & 0.007 & -6.006 & 246.996 & -0.000 & 0.006 & 0.376 \\
\hline CPWLAND & 0.009 & & 0.000 & 0.000 & 0.013 & 0.707 & 0.008 & 0.000 & 0.000 & 0.001 & 0.043 & 0.650 \\
\hline HUMANLAND & 0.009 & & 6.117 & -0.000 & 0.014 & 0.606 & 0.009 & -0.940 & 21.195 & -0.002 & 0.049 & 0.313 \\
\hline Burn-ins & \multicolumn{6}{|c|}{$0.6 \mathrm{~m}$} & \multicolumn{6}{|c|}{$0.4 \mathrm{~m}$} \\
\hline & \multicolumn{6}{|c|}{$6 \mathrm{~m}$} & \multicolumn{6}{|c|}{$4 m$} \\
\hline Cor PMP & \multicolumn{6}{|c|}{0.99} & \multicolumn{6}{|c|}{ not applicable } \\
\hline
\end{tabular}


implied that countries separated by a sea or/and high geographical distance were characterised by less similar production structures. These results should come as no surprise, as geographical distance is associated with higher transportation costs and hampering the possibility of vertical integration through global value chains or multinationals.

The difference in real GDP per capita (RGDPpc) was characterised by PIP equal to one regardless of the employed prior structure. Positive PM suggested a negative relationship between RGDPpc and structural similarity. This result can be traced back to Linder hypothesis (1961), as countries with a comparable level of development are characterised by more similar consumption structures. ${ }^{2}$ In turn, consumption structures affect production structures. This conclusion should be confronted with the notion of the U-shaped relationship between real GDP per capita and specialisation proposed by Imbs and Wacziarg (2003). Accordingly, as GDP per capita of a country increases, the country diversifies its production structure until it encounters a critical level of GDP per capita, henceforth re-specializing. Consequently, if countries above the critical level of GDP per capita are specializing, the result obtained here suggests that they must specialise within the same sectors, as their GDP per capita levels converge.
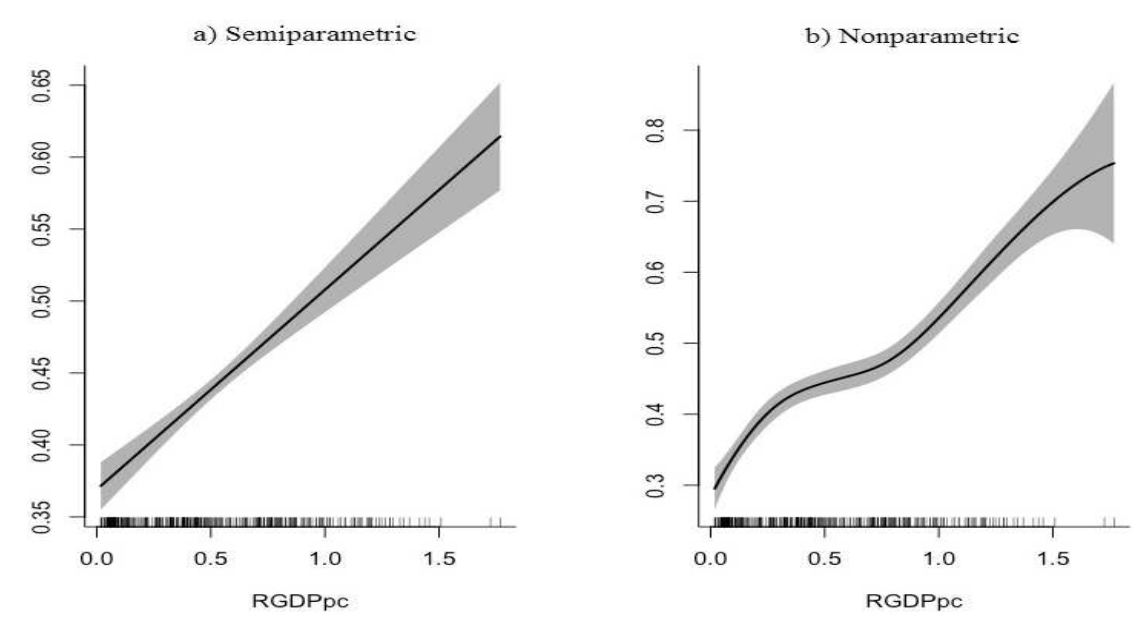

Figure 1. Semiparametric and nonparametric estimation results (dependent variable KSI) Source: own elaboration.

The product of real GDP per capita (RGDPpCPROD) was characterised by the PIP higher than prior inclusion probability, and it entered with a positive posterior mean in all BMA specifications. This puzzling result implied that the higher level of RGDPpCPROD is associated with a lower similarity of productions structures. When structural similarity was regressed on RGDPpCPROD alone, the point estimate was not statistically significant, and only the inclusion of RGDPpc made it statistically significant (at 0.001 level). The jointness measure of Lay and Steel (2007) classifies this pair of variables as strong complements: their joint inclusion in the model vastly improves it compared to the inclusion of each of these variables alone (the value of Lay and Steel (LS) measure was 6.84). This result suggests that there was a nonlinear relationship between RGDPpc and structural similarity. A line fitted with a penalised spline smoother (Ruppert \& Carroll, 2000) with 95\% confidence interval is shown in panel b) of Figure 1. The decreasing GDP per capita distance raised structural similarity at an increasing rate near the beginning of the horizontal axis. When a semi-parametric regression (Ruppert et al., 2000) was run with all robust variables, the relationship between KSI and RGDPpc became linear in panel a) of Figure 1. A more interesting feature of the graph is the cut off around 0.3 for panel $b$ ) and 0.37 for panel a). Following the Linder hypothesis, this might suggest that a structural similarity can be driven up by the similarity in the stage of development only until some point for two reasons. Firstly, differences in preferences inherent for specific countries - associated with tradition, history, and culture of given

\footnotetext{
2 The impact of income on economic structure has been widely confirmed in the literature (Bonatti \& Felice, 2008; Foellmi \& Zweimüller, 2008; Duarte \& Restuccia, 2010; Boppart, 2014; Caron et al., 2014, 2017; Buera et al., 2015), in which authors model the transition of economic structures on demand-side by using non-homothetic preference and changes in relative prices among sectors induced by disproportionate growth rate of technological progress.
} 
countries - might maintain some fixed levels of consumption structure difference unaffected by changes in GDP per capita. Secondly, even if the two countries shared identical preferences and consumptions structures, their production structures could differ due to differences in natural resources and factor abundance. One problem that could not be dealt with within the BMA framework was simultaneity, which I consider in the next subsection.

The absolute value of the difference of ratios of capital to arable land (CAPARABLE) was associated with posterior inclusion probability equal to 0.59 and 0.36 for Strategy I and II, respectively. A negative posterior mean was somewhat puzzling, as large differences in relative factor abundance are associated with less dissimilar production structures. The jointness measure suggested that the variable was a complement of RGDPpc and RGDPpCPROD (LS measure 2.73 and 2.74 for RGDPpc and RGDPpcPROD, respectively). As those variables were proxies for similarities in countries' prosperity, CAPARABLE could have also been used as a proxy for the stage of development, capturing differences not inherent to GDP per capita. With this interpretation, higher differences at the stage of development would be associated with lower structural similarities. A dummy variable indicating that both countries were members of the European Union before 2004 (OLDEU) was robust under Strategy II, with posterior inclusion probability equalling 0.56. Although, the dummy variable was fragile under Strategy I, with PIP equalling 0.303. Surprisingly, a positive posterior mean indicated that old EU member states were on average characterised by less similar production structures. When the variable OLDEU was included in the model alone, it was characterised by a negative coefficient, and it was statistically significant at any conventional level. The inclusion of RGDPpc in the model changed the sign of the coefficient, indicating that after controlling for differences in the state of development, the effect of long-lasting integration was associated with a lower degree of structural similarity. As the EU15 were able to enjoy the benefits of the common market for a longer period of time, the countries could have specialised according to their comparative advantage. This conclusion is strongly supported in the empirical literature (Amiti, 1999; Brülhart, 1998a, 1998b; Brülhart \& Traeger, 2005; Combes \& Overman, 2004; Midelfart-Knarvik \& Overman, 2002; MidelfartKnarvik et al., 2003; Storper et al., 2002). Midelfart-Knarvik et al. (2002) go even further, showing that European economies are becoming less similar in terms of the structure.

Unsurprisingly, intra-industry trade in intermediate goods (IIT) was listed as one of the robust determinants of similarity of production structures. The variable was characterised by PIP equal to 0.85 and 0.62 for Strategy I and II, respectively, while the posterior mean was negative and ranged from 0.17 to -0.12 . This result should not be unexpected, as the similarity of production structures was most likely accompanied by high intensity of intra-industry trade. Still, a critical question was whether the direction of influence goes from IIT to KSI or the other way around. I consider this issue in the next section. Bilateral trade (LNTRADE) was also classified as robust with 0.54 and 0.68 PIP in Strategy I and Strategy II, respectively. The posterior mean ranged from -0.014 to -0.009 , indicating that higher trade is associated with more similar production structures. An economic interpretation here was somewhat troublesome, as comparative advantage theories of trade predict that higher trade promotes less similar production structures through specialisation. On the other hand, theories incorporating trade as a mean of technological spillovers (e.g. Grossman \& Helpman, 1991a) provide an alternative explanation. By facilitating technological transfers, trade can serve as a mechanism of promoting technology-based specialisation with patterns resembling those of the trading partners. Nevertheless, there remains the issue of possible reverse causality between international trade and structural similarity.

Differences in the number of patents per one million inhabitants (PATENT) were characterised by PIP higher than the prior value and positive posterior mean under both BMA specifications. PATENT was a proxy for differences in technological development and technological potential of two countries. The positive posterior mean suggested that differences in technological development were associated with lower structural similarity. The role of technology in the structural change is extensively studied in economic models (e.g. Grossman \& Helpman, 1980, 1991b) and empirical research (e.g. Chiappini, 2014), especially in the context of innovation and entrepreneurship (Crudu, 2019) as well as catchingup economies (Paliokaite, 2019). The results for PATENT affirm the role of technology for structural similarities. Differences in foreign direct investment flows (FDID) - with PIP equalling 0.51 for Strategy I- was another robust determinant of structural similarity. A posterior mean equal to 0.003 suggested 
that differences in FDI flows were associated with dissimilar production structures. As FDI contributes to vertical integration, they might promote the development of similar production structures between origin and host countries. The results obtained in this research suggest that host countries' flows might assimilate production structures of investing countries. Nevertheless, we may expect host countries to be at the lower parts of the value chain, with sectoral classification remaining unchanged. The existence of a link between FDI, vertical integration, and specialisation is supported by Vogiatzoglou (2007) for Asia, while by Dupuch and Maizer (2005) and Vechiu and Makhlouf (2014) for the EU.

Finally, the last two variables classified as robust under both strategies were the absolute value of the difference between Bayesian Corruption Index measures (BCIDIFF) and the product of the Bayesian Corruption Index (BICPROD) for two countries. The posterior inclusion probability for BCIPROD was equal to 1 , while the posterior mean was positive under both specifications. BCIDIFF was also characterised by a positive posterior mean and PIP equal to 0.76 and 0.68 for I and II Strategy, respectively. In effect, the analysis suggests that, on the one hand, countries characterised by a vast difference in the level of corruption have dissimilar production structures, and in general, countries with high levels of corruption are structurally heterogeneous on the other. Moreover, jointness measures showed that the two variables are strong complements (LS measure: 3.75 ), which meant that each of them was carrying different information about the variation in KSI. BCIPROD included alone in the model was insignificant, but upon the inclusion of BCIDIFF it was statistically different from zero at any conventional level. Additionally, BCDIFF was a strong complement of RGDPpc and RGDPpCPROD, while BCIPROD of RGDPpcPROD with LS measures equalled $3.75,3.79$, and 6.84 , respectively. It would seem that all four variables amplified their influence on structural similarity, and each of them was associated with a different part of the variability in KSI. Bilateral relationships of all the aforementioned variables and KSI were depicted in the scatterplot matrix in Figure 2. So far, neither theoretical nor empirical links between corruption and structural similarity or specialisation have been established, although Chang et al. (2015) provide a model in which corruption and growth can coexist in the presence of specialisation.

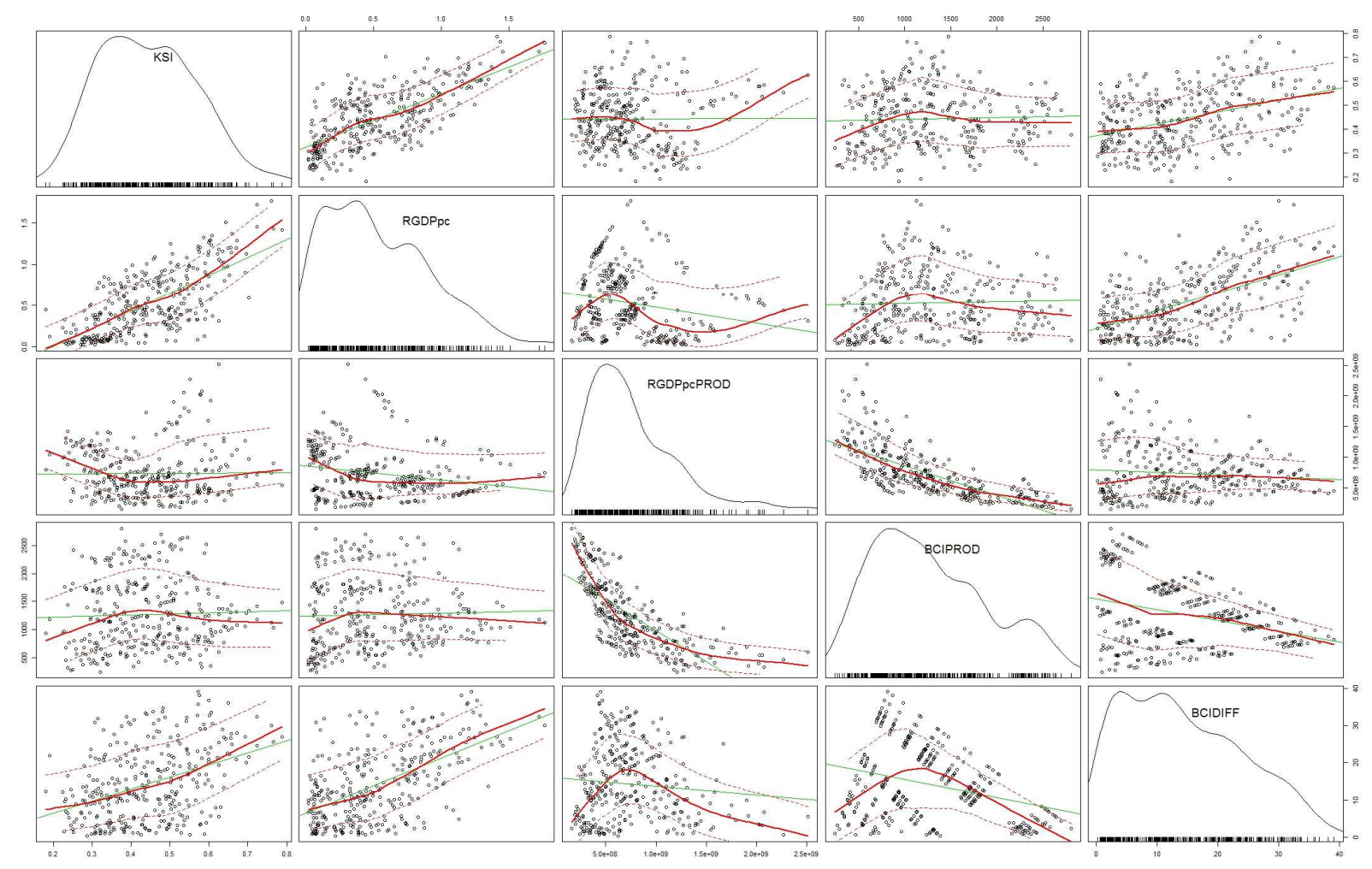

Figure 2. Bivariate relationships between KSI, RGDPpc, RGDPpCPROD, BCIPROD, BCIDIFF

Note: OLS fitted line is green, while the results of nonparametric regression along with 0.95 confidence band is red. Source: own elaboration. 
Turning to standardised posterior means, GDP per capita difference, Bayesian Corruption Index product exerted the most substantial impact on structural similarity, followed by GDP per capita product and marine border dummy. The strength of the influence of intra-industry trade, differences in the Bayesian Corruption Index, bilateral trade, and differences in the number of patents was considerably smaller. For all other variables, the values of posterior means are sensitive to the choice of estimation strategy.

The above results went through vast robustness checks in terms of dilution prior, g prior, and model prior structure. ${ }^{3}$ The presented results are not sensitive to changes in prior specifications, yet some comments are due. The specifications of BMA with RIC g prior - including binomial model prior - reproduce results comparable with the ones encountered in Strategy I. In specifications with betabinomial, prior results are comparable with Strategy II. This brings overwhelming evidence that $M B$, RGDPpc, BCIPROD, RGDPpCPROD, IIT, BCIDIFF, PATENT, and LNTRADE are, in fact, robust determinants of structural similarity. Moreover, LNDGEO, CAPARABLE, FIDD, and OLDEU are robust within the sets of priors associated with Strategy I and II, respectively, which engenders more arguments for their robustness. When one of the g priors not recommended for the data at hand is used (Fernández et al., 2001), all the above variables are classified as robust. Furthermore, with ill-advised g priors - namely Hannan-Quinn (HQ) and unit information prior (UIP; Kass \& Wasserman, 1995) - the number of robust variables was vastly extended. Except for the variables presented in the main results, under UIP and $\mathrm{HQ}$, PIP higher than 0.5 characterised LAND, HUMAN, POPDIFF, CPW, CPWARABLE, TRANS, LNRGDPPROD, and LNPOPPROD. The values of PIP for those variables vary from specification to specification. In the last set of robustness checks, flexible priors were applied, namely Empirical Bayes g (George \& Foster, 2000; Hansen \& Yu, 2001) and hyper-g (Liang et al., 2008; Feldkircher \& Zeugner, 2009). Under flexible priors, except for the variables in the main results, LAND, HUMAN, POPDIFF, and CAPLAND had PIP higher than prior inclusion probability. The inclusion of these additional variables in the robust set might be explained by higher susceptibility of these priors to the noise in the data. This explanation is rather convincing, as even when all the variables from the main results are included in the model, they can only account for $75.6 \%$ of the variability in structural similarity.

\section{Panel data setting}

The results obtained with the Moral-Benito (2016) approach to Bayesian model averaging for dynamic panel models with weakly exogenous regressors and fixed effects are depicted in Table 3. Raftery (1995) considers variables robust if $\left|\frac{P M}{P S D}\right|$ is higher than 1 , which implies that variables improve the model, while Masanjala and Papageorgiou (2008) advocate $\left|\frac{P M}{P S D}\right|$ higher than 1.3, which corresponds to a $90 \%$ confidence interval. The most stringent condition for robustness is proposed by Sala-I-Martin et al. (2004), who require the absolute value of the ratio to be higher than 2 , associated with a $95 \%$ confidence interval. According to this scheme, differences in the level of corruption, real GDP product, intra-industry trade, and total trade are robust, while all other variables are fragile. The fragility of differences in capital to arable land ratio, the number of patents, GDP per capita, and foreign direct investments is understandable. Those variables influence economic structure in the long run, while their impact in the shorter period is somewhat limited.

Posterior mean on the lagged structural convergence (KSIlag) is slightly above one, and it is characterised by almost 29 times smaller posterior standard deviation. The result indicates persistence in terms of structural similarity and shows the pattern of divergence in EU member states over the analysed period. Intra-industry trade positively influences structural similarity even in the short run, while the outcome supports a long run prediction. Consequently, the results obtained in the cross-sectional setting remain valid after accounting for reverse causality. Conversely, accounting for reverse causality changes the sign of the posterior mean in the case of international trade and supports the relationship between trade and economic structure described in neoclassical theories. Combined results from cross-sectional and panel data setting show that - in the short-run - intensified trade ties contribute

\footnotetext{
${ }^{3}$ Results are not reported here for brevity but are available upon request.
} 
to structural divergence, yet the countries characterised by higher bilateral trade are also more similar in terms of sectoral composition.

Table 3. BMA statistics for panel setting

\begin{tabular}{|c|c|c|c|c|}
\hline Variable & PIP & PM & PSD & PM/PSD \\
\hline KSIlag & - & 1.105 & 0.039 & 28.701 \\
\hline BICPROD & 0.998 & 0.002 & 0.009 & 0.241 \\
\hline BICDIFF & 0.998 & 0.029 & 0.014 & 2.109 \\
\hline CAPARABLE & 0.997 & -0.003 & 0.007 & -0.457 \\
\hline PATENT & 0.989 & 0.004 & 0.005 & 0.741 \\
\hline RGDPpcPROD & 0.985 & -0.048 & 0.014 & -3.369 \\
\hline IIT & 0.982 & -0.020 & 0.006 & -3.564 \\
\hline LNTRADE & 0.981 & 0.065 & 0.010 & 6.269 \\
\hline RGDPpc & 0.970 & 0.002 & 0.010 & 0.175 \\
\hline FDI & 0.914 & 0.001 & 0.002 & 0.500 \\
\hline
\end{tabular}

Source: own study.

BICPROD turned out to be fragile while BICDIFF - robust, and the sign of posterior mean for differences in the level of corruption was the same as in the cross-sectional analysis. Changes in the level of corruption affected structural convergence in the short and long run. Accounting for reverse causality demonstrated that the causality goes from corruption to economic structure and not the other way around. Differences in the level of development were fragile, suggesting that they impact economic structures in the long run. Conversely, the product of real GDP per capita was robust, and the posterior mean for RGDPpcPROD had the same sign as in the cross-sectional exercise. Accordingly, as countries are getting richer and converging in terms of the level of development, they are converging in terms of economic structures both in the short and long run. The results also show that the causality goes from the level of development to economic structures, which provides further evidence for theories that link changes in the level of income with structural change.

\section{CONCLUSIONS}

The application of Bayesian model averaging allowed to identify eight variables that prove to be robust determinants of structural similarity in the long run, regardless of the employed prior specification, namely marine border dummy, difference and product of real GDP per capita, difference and product in Bayesian Corruption Index, intra-industry trade, difference in number of patents per one million inhabitants, and the volume of bilateral trade. Furthermore, under multicollinearity dilution prior, geographical distance, difference in capital to arable land ratio, and difference in FDI flows are classified as robust. Finally, the dummy variable representing membership in the European Union before 2004 is robust only under tessellation prior. Interestingly, the differences in absolute and relative factor abundance do not seem to influence the degree of structural convergence.

The results suggest that there is a strong negative relationship between GDP per capita distance and structural similarity, although income convergence can bring structural similarity only until some point. If the link between the variables is driven by demand, there might be some natural constraints imposed by differences in culture and in available resources and factor endowments. Changes in the level of development impact economic structures in both the short and the long run. Moreover, once the effect of GDP per capita distance has been accounted for, the impact of the European common market on structural similarities becomes negative. This notion is consistent with 'the Krugman View' (1993) and predictions of economic geography in general, along with the Imb's and Wacziarg's (2003) U-shaped specialisation curve. Accordingly, further European integration may lead to structural divergence. On the one hand, less similar production structures might be associated with international specialisation according to comparative advantage and the effective allocation of resources. On the other hand, they pose a risk of asymmetric shocks and an increased need for independent monetary policy. 
Bilateral trade plays a prominent role in the promotion of structural convergence. It is associated with more similar production structures in the long run, and a theoretical explanation for this phenomenon must be found outside the reality of comparative advantage theories. Accounting for reverse causality in the above study showed that international trade leads to structural convergence in the short run, along with the predictions of neoclassical trade models. Intra-industry trade affects structural similarity positively in both the short and long run. This result indicates the prominent role of the integration of production processes in European value chains for structural convergence. Accounting for reverse causality in the above study assured that the direction of causality goes from higher trade in intermediate inputs within the same sectors to changes in economic structure. In turn, this notion is reinforced even further by the relevance of FDI flows in explaining the structural similarity. We should emphasise that this type of integration is beneficial from the viewpoint of the stability of the currency union in Europe. Furthermore, technological advancements are yet another driving force of structural similarity. National governments could speed up the process of structural convergence by establishing or improving the coordination of supranational research and development at the European level. At the same time, the authorities should remember these changes take effect in the long run.

Finally, what influences structural similarity is corruption as both differences in the level of corruption and its overall level are associated with less similar production structures in the long run. Changes in the level of corruption impact structural similarity in the short run as well, and the panel exercise above showed that the direction of influence goes from corruption to economic structures. Still, this relationship requires further investigation as it has not yet received attention in practical and theoretical models. Moreover, we should highlight the main differences between the results obtained in the study presented above and in the existing empirical literature. Wacziarg (2004) and Crespo and Fontoura (2009) report a significant role of differences in factor abundance. On the contrary, this article classified differences in both absolute and relative factor abundance as fragile. The analysis of the impact of differences in factor abundance gives significant results for many models with the data at hand. However, the results are not robust as they heavily rely upon the inclusion and exclusion of specific variables. Previous research reports a significant impact of these variables because it neglects to account for model uncertainty. Future research should give this matter more attention.

\section{REFERENCES}

Amiti, M. (1999). Specialization patterns in Europe. Review of World Economics, 135(4), 573-593. https://doi.org/10.1007/BF02707385

Baxter, M., \& Kouparitsas, M. (2003). Trade structure, Industrial structure, and International Business Cycles. American Economic Review, 93(2), 51-56. https://doi.org/10.1257/000282803321946796

Androniceanu, A., Gherghina, R., \& Ciobanasu, M. (2019). The interdependence between fiscal public policies and tax evasion. Administratie si Management Public, 32, 32-41. https://doi.org/10.24818/amp/2019.32-03

Beck, K. (2013). Determinants of Business Cycles Synchronization in the European Union and the Euro Area. Equilibrium. Quarterly Journal of Economics and Economic Policy, 8(4), 25-48. https://doi.org/10.12775/EQUIL.2013.025

Beck, K. (2014). Determinanty synchronizacji cykli koniunkturalnych w krajach Unii Europejskiej w latach 19902007. Gospodarka w Teorii i Praktyce, 1(34), 5-20.

Beck, K. (2017). Bayesian Model Averaging and jointness Measures: Theoretical Framework and Application to the Gravity Model of Trade. Statistics in Transition New Series, 18(3), 393-412. https://doi.org/10.21307/stattrans-2016-077

Beck, K. (2019). What drives business cycle synchronization? BMA results from the European Union. Baltic Journal of Economics, 19(2), 248-275. https://doi.org/10.1080/1406099X.2019.1652393

Beck, K. (2020a). Decoupling after the crisis: Western and eastern business cycles in the European Union. Eastern European Economics, 58(1), 68-82. https://doi.org/10.1080/00128775.2019.1656086

Beck, K. (2020b). What drives international trade? Robust analysis for the European Union. Journal of International Studies, 13(3), 68-84. https://doi.org/10.14254/2071-8330.2020/13-3/5

Beck, K. (2020c). Migration and business cycles: testing the OCA theory predictions in the European Union. Applied Economics Letters. https://doi.org/10.1080/13504851.2020.1798339 
Beck, K., \& Janus, J. (2013). Aggregate Demand Disturbances in the Visegrad Group and the Eurozone. Entrepreneurial Business and Economics Review, 1(3), 7-20. https://doi.org/10.15678/EBER.2013.010302

Beck, K., \& Stanek, P. (2019). Globalization or regionalization of stock markets? The case of central and eastern European countries. Eastern European Economics, 57(4), 317-330. https://doi.org/10.1080/00128775.2019.1610895

Bekiros, S., Nguyen, D.K., Uddin, G.S., \& Sjö, B. (2015). Business cycle (de)synchronization in the aftermath of the global financial crisis: Implications for the Euro area. Studies in Nonlinear Dynamics \& Econometrics, 19(5), 609-624. https://doi.org/10.1515/snde-2014-0055

Bieleková, E., \& Pokrivč́k, J. (2020). Determinants of International Beer Export. AGRIS on-line Papers in Economics and Informatics, 12(2), 17-27. https://doi.org/10.7160/aol.2020.120202

Bilan, Y., Mishchuk, H., Samoliuk, N., \& Mishchuk, V. (2020). Gender discrimination and its links with compensations and benefits practices in enterprises. Entrepreneurial Business and Economics Review, 8(3), 189-204. https://doi.org/10.15678/EBER.2020.080311

Bonatti, L., \& Felice, G. (2008). Endogenous growth and changing sectoral composition in advanced economies. Structural Change and Economic Dynamics, 19(2), 109-131. https://doi.org/10.1016/j.strueco.2007.07.002

Boppart, T. (2014). Structural Change and the Kaldor Facts in a Growth Model With Relative Price Effects and Non-Gorman Preferences. Econometrica, 82(6), 2167-2196. https://doi.org/10.3982/ECTA11354

Brülhart, M. (1998a). Economic Geography, Industry Location, and Trade: The Evidence. The World Economics, 21(6), 775-801. https://doi.org/10.1111/1467-9701.00163

Brülhart, M. (1998b). Trading Places: Industrial Specialization in the European Union. Journal of Common Market Studies, 36(3), 319-346. https://doi.org/10.1111/1468-5965.00113

Buera, F.J., Kaboski, J.P., \& Rogerson, R. (2015). Skill-based structural change. NBER Working Paper, 21165. Retrieved from https://www.nber.org/system/files/working_papers/w21165/w21165.pdf on October 23, 2020.

Caron, J., Fally, T., \& Markusen, J. (2014). International Trade Puzzles: A solution Linking Production and Preferences. The Quarterly Journal of Economics, 129(3), 129-173. https://doi.org/10.1093/qje/qju010

Caron, J., Fally, T., \& Markusen, J. (2017). Per Capita Income and the Demand for Skills. NBER Working Paper, 23482. Retrieved from https://www.nber.org/system/files/working_papers/w23482/w23482.pdf on October 23, 2020.

Caselli, F., \& Coleman II, W.J. (2001). The U.S. Structural transformation and Regional Convergence: A Reinterpretation. Journal of Political Economy, 109(3), 584-616. https://doi.org/10.1086/321015

Chang, J-J., Lu, H-c., \& Tsai, H-f. (2015). Corruption, growth, and increasing returns to production specialization. International Journal of Economic Theory, 11(3), 329-345. https://doi.org/10.1111/ijet.12067

Chiappini, R. (2014). Persistence vs. mobility in industrial and technological specialisations: evidence from 11 Euro area countries. Journal of Evolutionary Economics, 24(1), 159-187. https://doi.org/10.1007/s00191-013-0331-7

Campos, N.F., \& Macchiarelli, C. (2016). Core and Periphery in the European Monetary Union: Bayoumi and Eichengreen 25 years later. Economic Letters, 147(C), 127-130. https://doi.org/10.1016/j.econlet.2016.07.040

Combes, P.P., \& Overman, H.G. (2004). The spatial Distribution of Economic Activities in the European Union. In J.V. Henderson \& J.F. Thisse (Eds.), Handbook of Regional and Urban Economics. Volume 4 (pp. 2845-2909). Amsterdam: Elsevier. https://doi.org/10.1016/S1574-0080(04)80021-X

Coppola, A., lanuario, S., Chinnici, G., Di Vita, G., Pappalardo, G., \& D'Amico, D. (2018). Endogenous and Exogenous Determinants of Agricultural Productivity: What Is the Most Relevant for the Competitiveness of the Italian Agricultural Systems?. AGRIS on-line Papers in Economics and Informatics, 10(2), 33-47. ISSN 18041930. https://doi.org/10.7160/aol.2018.100204

Crespo, N., \& Fontoura, P. (2009). Determinant Factors of Structural Similarity at the Regional Level: evidence from Portugal. ISEG Department of Economics Working Papers, 28. Retrieved from https://depeco.iseg.ulisboa.pt/wp/wp282009.pdf on October 23, 2020.

Crudu, R. (2019). The role of innovative entrepreneurship in the economic development of EU member countries. Journal of Entrepreneurship, Management and Innovation, 15(1), 35-60. https://doi.org/10.7341/20191512

Degiannakis, S., Duffy D., \& Fillis, G. (2014). Business cycle synchronization in EU: A time-varying approach. Scottish Journal of Political Economy, 61, 348-70. https://doi.org/10.1111/sjpe.12049

Doppelhofer, G., \& Weeks, M. (2009). Jointness of Growth Determinants. Journal of Applied Econometrics, 24(2), 209-244. https://doi.org/10.1002/jae.1046

Duarte, M., \& Restuccia, D. (2010). The Role of the Structural Transformation in Aggregate Productivity. The 
Quarterly Journal of Economics, 125(1), 1501-1552. https://doi.org/10.1162/qjec.2010.125.1.129

Dupuch, S., \& Maizer, J. (2002). Mobilité du capital et spécialisation en Union européenne. Revue Économique, 53(3), 483-492.

Eicher, T., Papageorgiou, C., \& Raftery, A.E. (2011). Determining Growth Determinants: Default Priors and Predictive Performance in Bayesian Model Averaging. Journal of Applied Econometrics, 26(1), 30-55. https://doi.org/10.1002/jae.1112

Feenstra, R.C. (2015). Advanced International Trade: Theory and Evidence. New Jersey: Princeton University Press.

Feenstra, R.C., Inklaar, R., \& Timmer, M.P. (2015). The Next Generation of the Penn World Table. American Economic Review, 105(10), 3150-3182. https://doi.org/10.1257/aer.20130954

Feldkircher, M., \& Zeugner, S. (2009). Benchmark Priors Revisited: On Adaptive Shrinkage and the Supermodel Effect in Bayesian Model Averaging. IMF Working Paper, 202. https://doi.org/10.5089/9781451873498.001

Felice, G. (2016). Size and composition of public investment, sectoral composition and growth. European Journal of Political Economy, 44, 136-158. https://doi.org/10.1016/j.ejpoleco.2016.07.001

Fernández, C., Ley, E., \& Steel, M. (2001). Benchmark priors for Bayesian model averaging. Journal of Econometrics, 100(2), 381-427. https://doi.org/10.1016/s0304-4076(00)00076-2

Ferroni, F., \& Klaus, B. (2015). Euro Area business cycles in turbulent times: convergence or decoupling?. Applied Economics, 47(34-35), 3791-815. https://doi.org/10.1080/00036846.2015.1021458

Fixler, D.J., \& Siegel, D. (1999). Outsourcing and productivity growth in services. Structural Change and Economic Dynamics, 10(2), 177-194. https://doi.org/10.1016/S0954-349X(98)00048-4

Foellmi, R., \& Zweimüller, J. (2008). Structural change, Engel's consumption cycles and Kaldor's facts of economic growth. Journal of Monetary Economics, 55(7), 1317-1328. https://doi.org/10.1016/j.jmoneco.2008.09.001

Foster, D., \& George, E. (1994). The Risk Inflation Criterion for Multiple Regression. The Annals of Statistics, 22(4), 1947-1975. https://doi.org/10.1214/aos/1176325766

George, E. (2010). Dilution priors: compensating for model space redundancy. In J. Berger, T. Cai, \& I. Johnstone (Eds.), Borrowing Strength: Theory Powering Applications-A Festschrift for Lawrence D. Brown (pp. 185165). Beachwood, OH: Institute of Mathematical Statistics. https://doi.org/10.1214/10-IMSCOLL611

George, E., \& Foster, D. (2000). Calibration and empirical Bayes variable selection. Biometrika, 87(4), 731-747. https://doi.org/10.1093/biomet/87.4.731

Grigoraş, V., \& Stanciu, I.E. (2016). New evidence on (de)synchronization of business cycles: Reshaping the European business cycle. International Economics, 147(C), 27-52. https://doi.org/10.1016/j.inteco.2016.03.002

Grodzicki, M. (2014). Structural Similarities of the Economies of the European Union. Equilibrium. Quarterly Journal of Economics and Economic Policy, 9(1), 93-117. https://doi.org/10.12775/EQUIL.2014.006

Grossman, G.M., \& Helpman, E. (1980). Comparative Advantage and Long-Run Growth. American Economic Review, 80(4), 796-815.

Grossman, G.M., \& Helpman, E. (1991a). Trade, knowledge spillovers, and growth. European Economic Review, 35(2-3), 517-526. https://doi.org/10.1016/0014-2921(91)90153-A

Grossman, G.M., \& Helpman, E. (1991b). Innovation and Growth in the Global Economy. Cambridge, MA: The MIT Press.

Hansen, M., \& Yu, B. (2001). Model selection and the principle of minimum description length. Journal of the American Statistical Association, 96(454), 746-774. https://doi.org/10.1198/016214501753168398

Herrendorf, B., Rogerson, R., \& Valentinyi, A. (2014). Growth and Structural Transformation. In P. Aghion, \& S.N. Durlauf (Eds.), Handbook of Economic Growth, Volume 2B. (pp. 855-941). Amsterdam: Elviser. https://doi.org/10.1016/B978-0-444-53540-5.00006-9

Hoeting, J., Madigan, D., Raftery, A.E., \& Volinsky, C. (1999). Bayesian Model Averaging: A Tutorial. Statistical Science, 14(4), 382-417. https://doi.org/10.1214/ss/1009212814

Höhenberger, N., \& Schmiedeberg, C. (2008). Structural convergence of European Countries. CEGE Discussion Paper, 75.

Imbs, J., Montenegro, C., \& Wacziarg, R. (2012). Economic integration and structural change. Retrieved from https://www.semanticscholar.org/paper/Economic-Integration-and-Structural-ChangeWacziarg/5c695098a815d67b92e485d730281651dc924059?tab=citations on October 23, 2020. 
Imbs, J., \& Wacziarg, R. (2003). Stages of Diversification. American Economic Review, 93(1), 63-86. https://doi.org/10.1257/000282803321455160

Janus, J. (2019). Real interest rate differentials between Central and Eastern European countries and the euro area. Equilibrium. Quarterly Journal of Economics and Economic Policy, 14(4), 677-693. https://doi.org/10.24136/eq.2019.031

Jones, C.I. (2013). Misallocation, Economic Growth, and Input-Output Economics. In D. Acemoglu, M. Arellano, \& E. Dekel (Eds.), Advances in Economics and Econometrics, Volume 2: Applied Economics (pp. 419-456). New York: Cambridge University Press. https://doi.org/10.1017/СB09781139060028.011

Kass, R.E., \& Raftery, A. (1995). Bayes Factors. Journal of the American Statistical Association, 90(430), 773-795. https://doi.org/10.1080/01621459.1995.10476572

Kass, R., \& Wasserman, L. (1995). A Reference Bayesian Test for Nested Hypotheses and Its Relationship to the Schwarz Criterion. Journal of the American Statistical Association, 90(431), 928-934. https://doi.org/10.1080/01621459.1995.10476592

Koren, M., \& Tenreyro, S. (2007). Volatility and Development. The Quarterly Journal of Economics, 122(1), 243287. https://doi.org/10.1162/qjec.122.1.243

Kinnunen, J., Androniceanu, A., \& Georgescu, I. (2019). The role of economic and political features in classification of countries in transition by Human Development Index. Informatica Economică, 23(4), 26-40. https://doi.org/10.12948/issn14531305/23.4.2019.03

Krugman, P. (1979). Increasing Returns, Monopolistic competition, and International Trade. Journal of International Economics, 9(4), 469-479. https://doi.org/10.1016/0022-1996(79)90017-5

Krugman, P. (1980). Scale Economies, Product Differentiation and the Pattern of Trade. American Economic Review, 70(5), 950-959.

Krugman, P. (1991). Geography and Trade. Cambridge, MA: The MIT Press.

Krugman, P. (1993). Lessons of Massachusetts for EMU. In F. Torres, \& F. Giavazzi (Eds.) Adjustment and Growth in the European Monetary Union (pp. 241-266). Cambridge/New York: Cambridge University Press. https://doi.org/10.1017/CB09780511599231.016

Krüger, J.J. (2010). Productivity And Structural Change: A Review Of The Literature. Journal of Economic Surveys. 22(2), 330-363. https://doi.org/10.1111/j.1467-6419.2007.00539.x

Ley, E., \& Steel, M. (2007). Jointness in Bayesian variable selection with applications to growth regression. Journal of Macroeconomics, 29(3), 476-493. https://doi.org/10.1016/j.jmacro.2006.12.002

Ley, E., \& Steel, M. (2009). On the Effect of Prior Assumptions in Bayesian Model Averaging with Applications to Growth Regressions. Journal of Applied Econometrics, 24(4), 651-674. https://doi.org/10.1002/jae.1057

Ley, E., \& Steel, M. (2012). Mixtures of g-priors for Bayesian model averaging with economic applications. Journal of Econometrics, 171(2), 251-266. https://doi.org/10.1016/j.jeconom.2012.06.009

Liang, F., Paulo, R., Molina, G., Clyde, M.A., \& Berger, J.O. (2008). Mixtures of g Priors for Bayesian Variable Selection. Journal of the American Statistical Association, 103(481), 410-423. https://doi.org/10.1198/016214507000001337

Linder, S.B. (1961). An Essay on Trade and Transformation. Stockholm: Almqvist \& Wicksell.

Madigan, D., York, J., \& Allard, D. (1995). Bayesian Graphical Models for Discrete Data. International Statistical Review, 63(2), 215-23. https://doi.org/10.2307/1403615

Masanjala, W., \& Papageorgiou, C. (2008). Rough and Lonely Road to Prosperity: a Reexamination of the Sources of Growth in Africa using Bayesian Model Averaging. Journal of Applied Econometrics, 23(5), 671-682. https://doi.org/10.1002/jae.1020

Matsuyama, K. (2009). Structural change in an interdependent world: a global view of manufacturing decline. Journal of the European Economic Association, 7(2-3), 478-486. https://doi.org/10.1162/JEEA.2009.7.2-3.478

Midelfart-Knarvik, K.H., \& Overman, H.G. (2002). Delocation and European integration: is structural spending justified?. Economic Policy, 17(33), 321-359. https://doi.org/10.1111/1468-0327.00091

Midelfart-Knarvik, K.H., Overman, H.G., Redding, S.J., \& Venables, A.J. (2002). Integration and Industrial special-

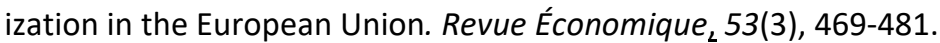

Midelfart-Knarvik, K.H., Overman, H.G., \& Venables, A.J. (2003). Monetary Union and the Economic Geography of Europe. Journal of Common Market Studies, 41(5), 847-868. https://doi.org/10.1111/j.1468-5965.2003.00466.x 
Moral-Benito, E. (2012). Determinants of Economic Growth: A Bayesian Panel Data Approach. Journal of Economics and Statistics, 94(2), 566-579. https://doi.org/10.1162/REST_a_00154

Moral-Benito, E. (2013). Likelihood-Based Estimation of Dynamic Panels with Predetermined Regressors. Journal of Business and Economic Statistics, 31(4), 451-472. https://doi.org/10.1080/07350015.2013.818003

Moral-Benito, E. (2016). Growth Empirics in Panel Data Under Model Uncertainty and Weak Exogeneity. Journal of Applied Econometrics, 31(3), 584-602. https://doi.org/10.1002/jae.2429

Ngai, L.R., \& Pissarides, C.A. (2007). Structural change in a multi-sector model of growth. American Economic Review, 97(1), 429-443. https://doi.org/10.1257/aer.97.1.429

OECD. (2013) Interconnected economies: benefiting from global value chains. Synthesis Report, OECD. Retrieved from https://www.oecd.org/sti/ind/interconnected-economies-GVCs-synthesis.pdf on October 23, 2020.

Olczyk, M., \& Lechman, E. (2011). Structural convergence among selected European countries. Multidimensional analysis. MPRA Paper, 33656. Retrieved from https://mpra.ub.uni-muenchen.de/33656/ on October 23, 2020.

Paliokaite, A. (2019). An innovation policy framework for upgrading firm absorptive capacities in the context of catching-up economies. Journal of Entrepreneurship, Management and Innovation, 15(3), 103-130. https://doi.org/10.7341/20191534

Parteka, A. (2009). Employment Specialisation in the Enlarged European Union. Ekonomia, 24, 6-21.

Peneder, M., \& Streicher, G. (2018). De-industrialization and comparative advantage in the global value chain. Economic Systems Research, 30(1), 85-104. https://doi.org/10.1080/09535314.2017.1320274

Popoola, O., Alege, P.O., Gershon, O., \& Asaleye, J.A. (2019). Human capital channels and productivity growth: Evidence from Nigeria. Economics and Sociology, 12(4), 59-73. https://doi.org/10.14254/2071789X.2019/12-4/3

Raftery, A.E. (1995). Bayesian Model Selection in Social Research. Sociological Methodology, 25, 111-163.

Ruppert, D., \& Carroll, R.J. (2000). Spatially-adaptitive penalities for spline fitting. Australian and New Zeland Journal of Statistics, 42(2), 205-223. https://doi.org/10.1111/1467-842X.00119

Ruppert, D., Wand, M.P., \& Carroll, R.J. (2000). Semiparametric Regression. New York: Cambridge University Press.

Sala-I-Martin, X., Doppelhofer, G., \& Miller, R. (2004). Determinants of Long-Term Growth: A Bayesian Averaging of Classical Estimates (BACE) Approach. American Economic Review, 94(4), 813-835. https://doi.org/10.1257/0002828042002570

Stachova, K., Stacho Z., Raišienè, A.G., \& Barokova, A. (2020). Human resource management trends in Slovakia. Journal of International Studies, 13(3), 320-331. https://doi.org/10.14254/2071-8330.2020/13-3/21

Standaert, S. (2015). Divining the level of corruption: a bayesian state-space approach. Journal of Comparative Economics, 43(3), 782-803. https://doi.org/10.1016/j.jce.2014.05.007

Stijepic, D., \& Wagner, H. (2015). Structural change, aggregate growth and government services. German Economic Association annual Conference 2015 (Muenster): Economic Development - Theory and Policy, 112904. Retrieved from https://www.econstor.eu/bitstream/10419/215647/1/ceames-dp-05rev.pdf on October 23, 2020.

Storper, M., Chen, Y., \& Paolis, F. (2002). Trade and the location of industries in the OECD and the European Union. Journal of Economic Geography, 2(1), 73-107. https://doi.org/10.1093/jeg/2.1.73

Święcki, T. (2017). Determinants of structural change. Review of Economic Dynamics, 24, 95-131. https://doi.org/10.1016/j.red.2017.01.007

Van Biesebroeck, J. (2011). Dissecting intra-industry trade. Economic Letters, 111(2), 71-75. https://doi.org/10.1016/j.econlet.2010.10.004

van Neuss, L. (2019). The Drivers of Structural Change. Journal of Economic Surveys, 33(1), 309-349. https://doi.org/10.1111/joes.12266

Vechiu, N., \& Makhlouf, F. (2014). Economic integration and specialization in production in the EU27: does FDI influence countries' specialization?. Empirical Economics, 46(2), 543-572. https://doi.org/10.1007/s00181-013-0682-9

Vogiatzoglou, K. (2007). Vertical Specialization and New Determinants of FDI: Evidence from South and East Asia. Global Economic Review, 36(3), 245-266. https://doi.org/10.1080/12265080701561984

Wacziarg, R. (2004). Structural convergence. CDDRL Working Papers, 8. Retrieved from https://fsi-live.s3.uswest-1.amazonaws.com/s3fs-public/Structural_Convergence.pdf on October 23, 2020. 
Zellner, A. (1986). On Assessing Prior Distributions and Bayesian Regression Analysis with g Prior Distributions. In P.K. Goel \& A. Zellner (Eds.), Bayesian Inference and Decision Techniques: Essays in Honor of Bruno de Finetti. Studies in Bayesian Econometrics 6. New York: Elsevier.

Zeugner, S., \& Feldkircher, M. (2015). Bayesian Model Averaging Employing Fixed and Flexible Priors: The BMS Package for R. Journal of Statistical Software, 68(4), 1-37. https://doi.org/0.18637/jss.v068.i04

Zhang, Y., \& Clark, D.P. (2009). Pattern and Determinants of United States' Intra-industry trade. International Trade Journal, 23(3), 325-356. https://doi.org/10.1080/08853900903012310

\section{Author}

\section{Krzysztof Beck}

Economist, econometrician, researcher, academic lecturer, and Assistant Professor at the Lazarski University. Studied at the Cracow University of Economics and received a PhD in Economics at the Faculty of International Business and Economics at the Poznan University of Business and Economics. Recipient of the Statistics Poland Award for the best doctoral dissertation in Statistics and the National Bank of Poland's Award for the best doctoral dissertation in Economics. Lecturer on English-language double diploma program accredited by Coventry University. His research activities include participation in research projects among others financed by the National Science Center. The author of dozens of papers and couple books, mainly in the field of macroeconomics, international economics, and econometrics, published both in Polish and English; also the author of statistical software. His main interests include international economics, international business cycles, international trade, currency unions, macroeconomics, econometrics, applied econometrics, mathematical economics, Bayesian statistics, and programming.

Correspondence to: Dr. Krzysztof Beck, Lazarski University, ul. Świeradowska 43, 02-662 Warszawa, Poland, e-mail: beckkrzysztof@gmail.com

ORCID $\odot$ http://orcid.org/0000-0003-3679-2962

\section{Acknowledgements and Financial Disclosure}

Article was prepared within the research project "Structural and regional aspects of international business cycles" funded by the Poland's National Science Centre, on the basis of decision No. DEC-2019/35/D/HS4/03636.

\section{Conflict of Interest}

The author declares that the research was conducted in the absence of any commercial or financial relationships that could be construed as a potential conflict of interest.

\section{Copyright and License}

This article is published under the terms of the Creative Commons Attribution - NoDerivs (CC BY-ND 4.0) License http://creativecommons.org/licenses/by-nd/4.0/ 